Translating culture-specific items in Shazdeh Ehtejab: Examining Foreignization and Domestication

\author{
Shokri, Sobhan $\bowtie$ \\ University of Isfahan, Iran (sbn.shokri@gmail.com) \\ Ketabi, Saeed \\ University of Isfahan, Iran (s.ketabi@yahoo.com)
}

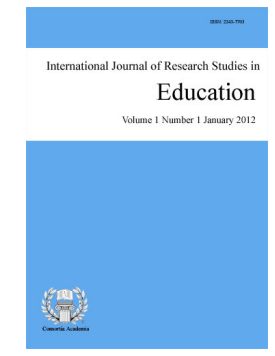

ISSN: 2243-7703 Online ISSN: 2243-7711

OPEN ACCESS

\title{
Abstract
}

The lexical presence of culture in a literary work mostly appears in form of culture-specific items. Due to cultural distance, translating these challenging elements, i.e. culture-specific items, is of real significance in the translation process. Translating these items entails, among others, adopting the dichotomy of Domestication or Foreignization. The present study sought to find which of the strategies was used more frequently in the English translation of the Persian literary masterpiece Shazdeh Ehtejab, translated by Buchan (2005). To do so, at first, thirty-four culture-specific items were extracted and then analyzed according to Newmark's categorization (1988) of culture-specific items. Then, these items were examined according to Aixela's model of translating culture-specific items (1996), which divides all the strategies into two broader categories of Domestication and Foreignization, to find the more frequent strategy. The result showed that Domestication with eighty-two percent was more frequent, which stood as the main approach of the translator. Moreover, as a subcategory of Domestication, synonymy was the most frequent strategy with thirty-nine percent. By applying domesticated equivalents, the translator hides the local color of the source text. The findings in this study have pedagogical implications for literary translators.

Keywords: culture-specific items; local color; Domestication; Foreignization; Shazdeh Ehtejab; Aixela's model 


\section{Translating culture-specific items in Shazdeh Ehtejab: Examining Foreignization and Domestication}

\section{Introduction}

Hongwei (1999, p. 121) believes in language as a portrait of culture and suggests, "language mirrors other parts of culture, supports them, spreads them and helps to develop others". This unique feature of language distinguishes it from all other aspects of culture and makes it remarkably significant for transferring culture. Hongwei then adds, "Language is the life-blood of culture and that culture is the track along which language forms and develops". Language and culture are two closely related concepts, both of which deal with the act of translation. Toury (2000, p. 200) defines translation as "a kind of activity which inevitably involves at least two languages and two cultural traditions". This definition makes clear that the involvement of culture in the act of translation is unavoidable. Therefore, knowing how to treat with linguistic and cultural gap is an asset for translators. These cultural gaps may be in form of lexicon, syntax, or in broader forms of ideology and way of life. Therefore, a translated text is expected to be the spot at which point a different culture appears, where a reader finds a cultural other and resistance. Regarding this, one of the challenges in the act of literary translation is translating the 'culture' within a text.

Katan (2009, p. 74) claims that as long as time passes, and new fields of studies come to an existence the concept of culture changes. Yet, one of the most quoted definitions of culture is given by the Edward Burnett Tylor in 1871. He defines it as "that complex whole which includes knowledge, belief, art, morals, law, customs and any other capabilities and habits acquired by man as a member of society" (Katan, 1999, p. 16). Another definition of culture is put forth by Vermeer. He believes that "culture consists of everything one needs to know, master and feel, in order to assess where members of a society are behaving acceptably or defiantly in their various roles" (Katan, 2009, p. 82). Translation, then, plays a settling medium in transferring culture through language. One who has the knowledge of two languages cannot necessarily translate between the two languages.

Translators face some challenges when translating items that are embedded in the source culture. These culture-bound or culture-specific items are frequently found in literary translation. One important feature of Shazdeh Ehtejab by Houshang Golshiri is its profound engagement to Persian culture. This novel was written in 1969 , but the setting of the novel is even set decades prior to its time, i.e. the Qajari period. Its setting obviously inquires certain linguistic cultural items, words and phrases related to material culture of food, clothes, house, transportation, or situational ones, occupations, and proper names. Golshiri enjoys creating the past and almost the forgotten atmosphere of Iran in the time of the publication of this novel. This is called cultural translation; however, cultural Translation is used in different contexts. It is used in post-colonial studies to refer to "the many indigenous languages of the world and the channel of exchange between them, translation may seem headed for the same fate in the time of cultural translation: to be dead and buried" (Trivedi, 2005). In this reading, in a narrower sense, it refers to "those practices of literary translation that mediate cultural differences, or try to convey extensive cultural background, or set out to represent another culture via translation" (Sturge, 2009). Sturge suggests two ways of rendering the cultural differences, leaning toward erotizing or leaning toward naturalizing.

Edward Hall in his Iceberg model, the Triad of Culture, divides aspects of culture into 3 levels: what is visible (above the waterline), Semi-visible, and Invisible (both below the waterline). He adds that translators should interpret cultural items regarding the extent to which frames of culture affects our translation in the process of translation. Hall suggests that translation scholars tend to focus on semi-visible and invisible levels, while practitioners are more concerned with the visible level.

In this context, however, cultural translation happens as a result of the cultural turn. Pym (2010, p. 149) 
defines cultural turn as " a term proposed by Snell-Hornby and legitimated by Lefevere and Bassnett, whereby translation studies should focus on the cultural effects of translation". He, then, states that the unit of translation, for each analysis, should move from text to culture. Yet, the trace of culture in language, and consequently, in translation is depicted as the culture-specific items.

\section{Literature Review}

\subsection{Culture-Specific Items}

The concepts of culture exist in a text in form of some linguistic signs or signifiers. These signifiers are called culture-specific, culture-bound, or cultural items, all of which refer to the same thing in translation studies. Aixela (1996, p. 54) states that cultural asymmetry between two linguistic communities is necessarily reflected in the discourse of their members. Baker (1992, p. 21) refers that these concepts may be "abstract or concrete, it may relate to a religious belief, a social custom, or even a type of food, which are called culture-specific items". The culture-specific items are the reflection of culture within the language. Therefore, it can be concluded that the culture-specific items can be defined as "elements of the text that are connected to certain concepts in the foreign culture (history, art, literature) which might be unknown to the readers of the target text" (Aixela, 1996, p. 14).

\subsection{The Problem of Equivalence or Untranslatability}

When translating culture-specific items, the literary translator encounters the whole issue of the translatability that is raised in the source text. Catford (1965, p. 94) distinguishes two types of untranslatability, linguistic and cultural. In linguistic untranslatability, "the functionally relevant features include some which are in fact formal features of the language of the SL text. If the TL has no formally corresponding feature, the text, or the item, is (relatively) untranslatable". For cultural untranslatability, "What appears to be a quite different problem arises, however, when a situational feature, functionally relevant for the SL text, is completely absent in the culture of which the TL is a part" (Catford, 1965, p. 99). Without making a separation between the linguistic and the cultural dichotomy, Popovič attempted to define the term. He distinguishes two types as well: The first is defined as " $a$ situation in which the linguistic elements of the original cannot be replaced adequately in structural, linear, functional, or semantic terms in consequence of a lack of denotation or connotation". The second type goes beyond the purely linguistic "a situation where the relation of expressing the meaning, i.e. the relation between the creative subject and its linguistic expression in the original does not find an adequate linguistic expression in the translation".

\subsection{Domestication and Foreignization}

Domestication and Foreignization are two translation methods, which offer linguistic and cultural guidance for the act of translation. These terms are suggested by the American translation theorist Venuti. He (1995, p. 17) defines translation as

a process by which the chain of signifiers that constitutes the source-language text is replaced by a chain of signifiers in the target language which the translator provides on the strength of an interpretation.

In this definition, it is clear that translation is a replacement of the ST's cultural signifiers in the TT. Nevertheless, Venuti (1995, p. 18) believes that there is a sort of violence that resides in the act of each translation, i.e. the re-formation of the foreign text in line with values, beliefs, and representations of the target language. He adds that this re-formation is always configured according to the hierarchies of TL, which in turn governs the production, circulation, and reception of texts. He mentions that this violence is to some extent ineluctable that is inherent in the translation process, and partly potential; intimating the final aim of translation 
Shokri, S., \& Ketabi, S.

is to bring back a cultural other as the same (Venuti, 1995, p. 18). However, a question which is raised here is how to deal with this violence? The answer to this question is given by Schleiermacher in his lecture on the different methods of translation in 1813. He argued, "Either the translator leaves the author in peace, as much as possible, and moves the reader towards him; or he leaves the reader in peace, as much as possible, and moves the author towards him" (Lefevere, 1977, p. 74). In other words, Schleiermacher allowed

the translator to choose between a domesticating method, an ethnocentric reduction of the foreign text to target-language cultural values, bringing the author back home, and a foreignizing method, an ethnodeviant pressure on those values to register the linguistic and cultural difference of the foreign text, sending the reader abroad (Venuti, 1995, p. 20).

Jeremy Munday (2008, p. 28) believes that Schleiermacher's preferred strategy is the first one, i.e. moving the reader toward the writer. In much the same way, Berman writes. Bad translation shapes toward the foreign culture a domestic attitude that is ethnocentric: 'generally under the guise of transmissibility, carries out a systematic negation of the strangeness of the foreign work'. Good translation aims to limit this ethnocentric negation: it stages 'an opening, a dialogue, a cross-breeding, a decentering' and thereby forces the domestic language and culture to register the foreignness of the foreign text (Venuti, 1998, p. 81). Schleiermacher's foreignizing translation is available in the selection process of the foreign text, "wherein the translator can resist the dominant discourse in Anglo-American culture by restoring excluded texts and possibly reforming the canon of foreign literatures in English" (Venuti, 1998, p. 81). He opposes merely sticking to the signified; for him, a translation can be foreignized by assimilating the signifiers of the foreign text, "the more closely the translation follows the turns taken by the original, the more foreign it will seem to the reader" (Lefevere, 1977, p. 78). Thus, Schleiermacher writes that in the first place [Foreignization], the translator, through his work, tries to replace for the reader the understanding of the original language that reader lacks. He tries to communicate to his readers the same image, the same impression his knowledge of the original language has allowed him to acquire of the work as it stands. In so doing he tries to move his readers toward his own point of view, which is essentially foreign to them (cited in Lefevere, 1997, p. 149). In this regard, Venuti (1995, p. 34) writes that

foreignizing translations that are not transparent, that eschew fluency for a more heterogeneous mix of discourses, are equally partial in their interpretation of the foreign text, but they tend to flaunt their partiality instead of concealing it.

However, Venuti defines Domestication as "an ethnocentric reduction of the foreign text to [Anglo- American] target language cultural values" (Venuti, 1995, p145). He also defines Foreignization as "an ethnodeviant pressure on [target-language cultural] values to register the linguistic and cultural difference of the foreign text, sending the reader abroad" (Venuti, 1995, p145). Hatim and Munday (2004, p. 338) defines Domestication as " $a$ translation strategy, discussed by Venuti, in which a transparent, fluent style is adopted in order to minimize the foreignness of an ST'. In brief, this process involves removing traces of the source culture in the target language.

\subsection{Identifying Culture-Specific Items}

To translate these culture-specific items, Newmark (1988) in his textbook of translation indicates that there will be a translation problem unless there is cultural overlap between the source and the target language and its readership. In other words, he says that there is a translation problem due to cultural gap or distance. Newmark categorizes the culture-specific items in five groups:

$>$ Ecology

$>\quad$ Material Culture: Food, Clothes, House, Transport

$>\quad$ Social Culture: Work or Leisure

> Social Organizations: Political and Administrative, Religious, Artistic 
$>$ Gestures and Habits

Another model is presented by Vlahov and Florin (Florin, 1993). They classified realia in various categories of geography, ethnography, and politics and society

\section{Methodology}

Deciding on what shall be called culture-specific can be misleading. They are referred to as challenging terms, since it is not easy to define what is exactly cultural and what is not. Therefore, cultural items are recognized by Newmark's categorization, a valid categorization that systematizes the cultural items. Then, the strategies in translating those items are identified by Aixela's model in order to obtain measurable results.

\subsection{Materials}

This is a qualitative case study research with a descriptive nature. The case study is the Persian literary masterpiece Shazdeh Ehtejab written by Houshang Golshiri in 1969, which is the only case used in this thesis. This novel is selected owing to its deep immersion in Persian culture. It is translated into English under the title of The Prince by James Buchan in 2005. All the found culture-specific items are the samples of this study, i.e. no specific sampling is used.

\subsection{Procedure}

A data mining method is used at first to extract the culture-specific items of Shazdeh Ehtejab as was said previously. However, determining what terms shall be called culture-specific is a demanding task; therefore Newmark's model (1988) is used to identify these items:

Table 1

Newmark's categorization of culture-specific items

\begin{tabular}{ll}
\hline \multicolumn{1}{c}{ Ecology } & \\
\hline Material Culture & Food \\
& Clothes \\
& House \\
\hline Social Culture & Transport \\
\hline Social Organizations & Work \\
& Leisure \\
\hline Gestures and Habits & Political and Administrative \\
\hline
\end{tabular}

The unit for analysis is taken as 'word,' not sentences, because Newmark's categorization analyzes words; in addition, this study has not anything to do with style. Consequently, Table 1 is used to identify the CSIs. The next step is to find their corresponding term in the English translation. At this point, the translation procedure of each culture-specific item is recognized. Numerous models have been proposed as translation procedures for translating non-cultural and technical words as well as cultural and more ordinary words. However, because CSIs have their own features, some translation models are proposed specifically for translating the CSIs. However, in this paper, Aixela's model (1996) is used to elucidate each strategy, since he divided all the strategies into Venuti's dichotomy of Domestication and Foreignization in order to obtain measurable results.

At last, the number of occurrence of each side shows which strategies are more frequent in translating Persian to English CISs by Buchan. Aixela, then, draws upon Venuti's broader terms of Domestication and Foreignization. He suggests that the procedures for conserving culture-specific items, or Foreignization, include repetition, transcription, non-cultural translation, and inter-textual/extra-textual gloss, while the procedures for 
Shokri, S., \& Ketabi, S.

substitution of culture-specific items, or Domestication, include synonymy, partial universalization, absolute universalization, naturalization, deletion, and autonomous creation.

\section{Table 2}

Aixela's model of translating culture-specific items

Repetition: The translators keep as much as they can of the original reference
Orthographic adaptation: Same as transcription
Linguistic (non-cultural) translation: when the translator chooses a denotatively very
close reference to the original
Extratextual gloss: When translators use footnote, endnote, glossary, and alike to add
information
Intratextual gloss: When translators include their gloss as an indistinct part of the text
$\begin{aligned} & \text { Synonymy: The translator resorts to some kind of synonym of parallel reference to avoid } \\ & \text { repeating the culture-specific item } \\ & \text { Limited universalization: Translator uses another, but closer SL reference in TT } \\ & \text { Absolute universalization: Translator chooses a neutral reference } \\ & \text { Naturalization: Translator brings the culture-specific item into the TL culture } \\ & \text { Deletion } \\ & \text { Autonomous creation: Translators put in some nonexistent cultural referent in the ST }\end{aligned}$

At last, in data analysis, the researcher uses a comparative model, i.e. features of the source culture-specific items are compared with the corresponding features of the translated texts (Williams \& Chesterman, 2002, p. 49).

\section{Analysis and Discussion}

\subsection{Classifying Culture-Specific Items}

The culture-specific items found in this novel were 34 items, which mostly fell under 'material culture' and 'social culture' categories. Below, they can be found with respect to Newmark's categorization:

Table 3

Newmark's categorization of culture-specific items

\begin{tabular}{|c|c|c|}
\hline \multicolumn{3}{|l|}{ Ecology } \\
\hline \multirow{4}{*}{ Material Culture } & Food & جوشانده \\
\hline & Clothes & سه طاقه شال، سردارى شمسه، نيمتنه، كلاه يوست بره اى، كليجه، \\
\hline & House & 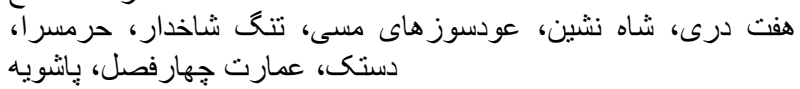 \\
\hline & Transport & 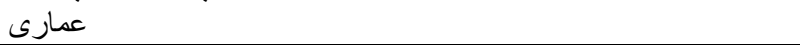 \\
\hline Social Culture & Work & 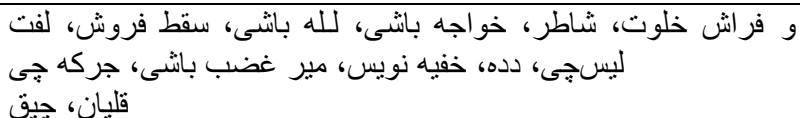 \\
\hline \multirow[t]{2}{*}{ Social Organizations } & $\begin{array}{l}\text { Political \& } \\
\text { Administrative }\end{array}$ & 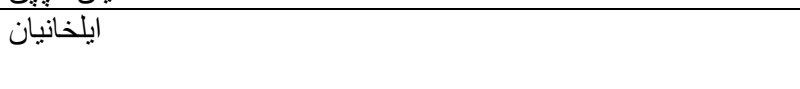 \\
\hline & $\begin{array}{l}\text { Religious } \\
\text { Artistic }\end{array}$ & كلاب باش، قارى، جزوه جیى، صيغه و عقدى \\
\hline
\end{tabular}

Gestures and Habits

\subsection{Data Analysis}

As is seen in Table 1, all the mined items are culture-specific. Most of the items are related to clothes, and work. The 34 CSIs are now investigated according to Aixela's model (Table 2) to find what strategies are applied by James Buchan: 
Translating culture-specific items in Shazdeh Ehtejab: Examining Foreignization and Domestication

Repetition: it is defined as when "the translators keep as much as s/he can of the original reference, e.g. Seattle is kept as Seattle". No such case was found in translation of the CSIs.

Orthographic adaptation: The Persian term Haram-Saraa is translated as 'Harem' that is a form of orthographic adaptation. In other words, it is referred to be a form of transcription and transliteration in another alphabet. This was the only case found, meaning 'a place for women or Andaruni.' That is to say, if it was in form a calque or loan word, then it was a repetition.

Linguistic (non-cultural) translation: Aixela declares that when the translator selects a denotatively very close reference to the original. Aixela makes it clear by adding that the translator increases its comprehensibility by offering a TL version, but still it is counted as the source culture (Aixela, 1996, p. 62).

Three cases were found for this type. Qelyan is translated as 'Water pipe.' It has been defined as a smoking device used chiefly in the Orient, made of a bowl mounted on a vessel of water, often provided with a long flexible tube terminating in a mouthpiece, and so arranged that the smoke is drawn from the bowl through the water where it is cooled and up the tube to the mouth, according to Webster's New Third International Unabridged Dictionary.

Another Persian term is Pashuye, which is defined in Dehkhoda as 1. A warm water used to clear the feet of a sick person, and 2. The pool's wall or water duct around it. Its translation is 'The next step down', which is linguistically defining where it is due to lack of the presence of this term in TL.

Golaab-Paash is translated as 'sprinklers of rosewater.' Sprinkler itself is a device that sprays water. Therefore, the source cultural item is appeared in TL.

Extratextual gloss: When translators use footnote, endnote, glossary, and alike to add information. 'Mir qazab baashi' in Dehkhoda is defined as 'the deathsman or agent that performs the king's decree' which is translated as Lord of Wrath with a footnote on the very same page. Therefore, the translator has used an extratextual gloss through the footnote to translate it. It is very clear that understanding the SL term is difficult for the TL readers without extra explanation.

Intratextual gloss: When translators include their gloss as an indistinct part of the text, i.e. no extra part (footnote, endnote, glossary and alike) is used in the TT. The only case for this is the use of Il-khaninan referring to 'the Il-khanate from the Mongol Empire, ruled by the Mongol House of Hulagu, founded in 1256.' Persian readers can certainly identify its historical aspects that governed in Iran for some years. However inevitably, English readers are not capable of identifying it as social culture category, let alone identifying it as political and administrative group. Therefore, extra information is needed here. Here, the translator resorts to saying Paramount chief of the Qashqai leaving out its main part, the Il-khanate. Yet, adding an intertextual gloss in the text itself, i.e. not in the footnote may come to readers' help.

The second division here focuses on domesticating translation method, which is called 'substitution' by Aixela:

Synonymy: Here, the translator resorts to some kind of synonym of parallel reference to avoid repeating the culture-specific item. It means that they stand in the same place within each of the source or target language systems. There were ten cases for synonymy:

a. Faraash Khalvat is defined 'as the special servant of the king's house' in Dehkhoda. However, the English equivalent 'valet' refers "A man's male servant, personal or not; a hotel servant" in The American Heritage Dictionary. Valet does not imply being servant of the king. Thus, the translator prefers a rather parallel element by using a synonymy.

b. Shaater is defines as 'those who walk in front of the king's carriage or horse with a special dress on' 
in Dehkhoda. 'Footmen' refers "a man employed as a servant to wait at table, attend the door, and run various errands, as in a palace". As is seen here, again a parallel reference is used.

c. Khaaje Baashi in Qajari period referred to 'the head of the castrated men which is idiomatically refers to those who do not pay attention to mundane matters' as defined in Amid, while in English, chief eunuch is used. This still distort the Persian source item.

d. Lale Baashi means 'a teacher who lives and works in the house of the host family.' It is translated to 'Tutor' which means "a private teacher" which is not necessarily in the house. Yet again, the translator made use of a parallel reference rather than the source specific term.

e. Joushandeh is defined in Amid as 'a herbaceous medicine which is boiled in the water and given to the ill person,' while the equivalent "Infusion" is defined as "the liquid product obtained by infusing" in the American Heritage Dictionary. Infusion is not necessarily medical, thus, 'herbal infusion' could be a better suggestion!

f. Jorke-chi is defined as 'those who encircle the hunt of the king so that the king could hunt it easily without having to move much.' Those who do such things are referred as Jorke chi in ST. Such concept can be hardly transferred unless there is extra explanation. However, the 'Beaters' in the American Heritage is referred to as "one who beats, or a person who drives wild game from under cover for a hunter". The second meaning is close but still not the same.

g. Armak refers to a cloth made from wool as suggested in Dehkhoda, while 'Pinafore' is "a sleeveless, apron-like garment usually having buttons or a sash at the back" as found in Random House. Again, a parallel reference is used.

h. Chopogh in Amid is defined as 'a smoking device made from wood with clay head, in which tobacco is placed in and smoked.' Its corresponding translation Pipe can be a parallel reference, not the same.

i. Dadeh is defined as 'a woman who lives with a family to raise their children,' but 'Nanny' is " $\mathrm{A}$ children's nurse" which indeed conceals the fact that dade is a female servant. Once more, a parallel and close reference is used.

j. Oud-suz mesi indicates 'a box which is used to burn lute.' 'Brass incense burner' is used as the corresponding item. Firstly, Mes is specifically copper, but brass refers to a type of metal alloy which consists of zinc and copper. The material is changed in TT. Secondly, in 'incense burner,' incense refers to "substance which gives of a sweet smell when burned". It is not same as the ST item. Therefore, a parallel reference is used.

k. Lefto-lis chi refers to 'stealing or using something owned by someone else for free and without his/her content or even knowledge.' The English translation 'Parasite' idiomatically refers to "One who lives off and flatters the rich; or a sycophant" according to American Heritage Dictionary. Therefore, a synonymy is used by applying a parallel reference.

Limited universalization: Translator uses another, but closer SL reference in TT. Seven cases were found in this study:

a. Amaari is defined as 'a carriage which is placed on camel or elephant so that people can sit in it' in Dehkhoda. 'Bier' however refers to "a platform or stand on which a corpse or a coffin containing a corpse rests before burial" in Collins English Dictionary. The translator thought of Amari as something to be distant for the target reader, therefore he chose a closer reference instead.

b. Qaari refers to 'the reader of Quran.' While 'Reciter' firstly refers to a person who read it by heart rather than merely reading it with a tone, which can be the equivalent of SL Haafez-e Quran. Again, a 
Translating culture-specific items in Shazdeh Ehtejab: Examining Foreignization and Domestication

closer reference is selected.

c. Tong-e Shaakhdaar refers to 'a jug either with a handle or made from pure silver' as is supposed for shakhdar in Amid. 'Crystal decanter' however refers to a jug made of crystal. This is another form, which in translator's opinion is closer to the target language.

d. Siqe or Aghdi are 'the two types of marriage in Islam (Shia).' The second concept is not available in English culture. The translator used 'wedded or temporary' that does not evince the same thing.

e. Dastak refers to many things. It can be 'a little hand or handle' or may refer to 'a notebook which is used for writing down business records.' However, in this context, 'Abe dastak raa be ham mizad,' it refers to a large container with a specific shape in SL culture. 'Basin' is used here as a closer reference.

f. Khafieh Nevis is used in Qajari period to refer to 'the witer of secret letters,' or even 'the police force' in Naser-e din Shah era. Anyhow, 'Spy' has a negative load which cannot be equivalent. Therefore, a closer reference is used once more.

g. Haft dari refers to 'a room with seven doors' according to Dehkhoda. 'Drawing room' is "a room where guests are received". Therefore, it is crystal clear that a closer reference is used.

Absolute universalization: It is similar to the previous one except that the translator chooses a neutral reference instead. The four cases found are:

a. Sardaari-e Shamse consists of two separate words. Sardari refers to 'a long royal robe for men with many folds in the back, which is dressed over other clothes,' and Shamse refers to 'a circular and inscribed picture or form' according to Moin and Dehkhoda respectively. While 'ceremonial tunic' refers to "a formal long upper garment worn by women". This a neutral reference, since it is not available in SL culture.

b. Shaah neshin refers to two things: 1. The place where the king sit in the room, or 2. A part of a room which is built like a large (roofed) balcony made of glass. While the English equivalent 'Dais' is used referring to "A raised platform, as in a lecture hall, for speakers or honored guests" according to American heritage Dictionary. At the most, dais can refer to the first one, not the second one, while second usage is more probable as for the archaic use of the word. Therefore, it can be said that a neutral reference for the second usage is employed by the translator.

c. Seqt Foroush is defined as 'retailer' in Amid. While 'Grocer' is "a person who sells foodstuffs and various household supplies," according to The American Heritage Dictionary. A neutral reference is used here.

d. Nim-Taneh in Amid is translated as a short clothes for men and women which only covers the upper part of the body. While 'Riding jacket' is used in TT, which means a clothes for riding!

Naturalization: Translator brings the culture-specific item into the TL culture felt as specific by TL culture. Literally, naturalization refers the process of becoming a citizen. Thus, it can be said that SL cultural items receive the license to appear in the TT, however it undergoes some changes to look accustomed to the TL features.

a. Emaarate Chaahaar-Fashl refers to a historical building and construction which is available all the year. While the English translation uses 'house' instead of something else which shows the archaic use if the Persian source, like 'Mansion.'

Deletion: SL item is not available in TT. 
Shokri, S., \& Ketabi, S.

a. Jozve-chi is completely deleted in TT. Nevertheless, sometimes it can be partial, i.e. keeping one part while deleting the main part.

b. Nata' refers to 'carpet of stall which is made up of leather' in Dehkhoda. In addition, it is defined as 'a tablecloth on which the sinner is decapitated' in Moin. Therefore, it is clear that it does not refer to the person itself. Here, the translator used 'decapitations.'

Autonomous creation: Translators put in some nonexistent cultural referent in the ST. Aixela states that it used rarely, however, it has been used 4 times here:

a. Se Taaqe Shaal is unquestionably 'three shawls' without referring to the material or place it is produced. However, 'Three Kashmir shawls' gives another reference "Kashmir" that is beyond the extent of the source text's reference. Therefore, a nonexistent referent is added.

b. Kolaahe Poust Barre-i refers to hat made up of the skin of lamb or alike, while the English translation 'Astrakhan hat' refers to a port city in southeast Russia. The source text only talks of a usual one, not a specific one.

c. Kolicheh refers to a bread as well as 'a robe that covers only half of the body' according to Moin. While, 'Jerkin' refers "a sleeveless and collarless short jacket worn by men or women". Once more, a nonexistent reference is used in TT.

Now, for ease of the reader, these items are presented in three columns in the table below. First column consists of the source cultural items, second column includes their translation in the TT, and third column shows the strategy used for their translation into TL according to Aixela's model, as was discussed already:

\section{Table 4}

Strategies applied in translation

\begin{tabular}{|c|c|c|}
\hline Source Text & Target Text & Strategy \\
\hline $\begin{array}{l}\text { سه طاقه شال } \\
\text { /Se taghe shāl/ }\end{array}$ & Three Kashmir shawls & Autonomous creation \\
\hline $\begin{array}{l}\text { هفت درى } \\
\text { /Haft dari/ }\end{array}$ & Drawing room & Limited universalization \\
\hline $\begin{array}{l}\text { فر ش خلوت } \\
\text { /Farāsh Khalvat/ }\end{array}$ & Valet & Synonymy \\
\hline $\begin{array}{l}\text { شاطر } \\
\text { /Shāter/ }\end{array}$ & Footmen & Synonymy \\
\hline $\begin{array}{l}\text { خواجه باشَى } \\
\text { /Khāje Bāshi/ }\end{array}$ & Chief eunuch & Synonymy \\
\hline $\begin{array}{l}\text { لهِ باشى } \\
\text { /Lale bashi/ }\end{array}$ & Tutor & Synonymy \\
\hline $\begin{array}{l}\text { سردارى شمسا } \\
\text { /Sardāri-e Shamsel }\end{array}$ & Ceremonial tunic & Absolute universalization \\
\hline $\begin{array}{l}\text { شاه نشين } \\
\text { /Shāh neshin/ }\end{array}$ & Dias & Absolute universalization \\
\hline $\begin{array}{l}\text { سقط فروش /Seght foroush/ } \\
\text { /Serol }\end{array}$ & Grocer & Absolute universalization \\
\hline $\begin{array}{l}\text { نيم تن } \\
\text { /Nim tane/ }\end{array}$ & Riding jackets & Absolute universalization \\
\hline جوشانده & Infusion & Synonymy \\
\hline $\begin{array}{l}\text { عمارى } \\
\text { /Amāri/ }\end{array}$ & Bier & Limited universalization \\
\hline
\end{tabular}


Translating culture-specific items in Shazdeh Ehtejab: Examining Foreignization and Domestication

Table 4 ... continued

\begin{tabular}{|c|c|c|}
\hline Source Text & Target Text & Strategy \\
\hline $\begin{array}{l}\text { كلاه يوست بره إه } \\
\text { /Kolāh-e Pust barei/ }\end{array}$ & Astrakhan hat & Autonomous creation \\
\hline $\begin{array}{l}\text { كلاب ياش } \\
\text { /Golāb pāsh/ }\end{array}$ & Sprinklers of rosewater & Linguistic translation \\
\hline $\begin{array}{l}\text { قارى } \\
\text { /Ghāri/ }\end{array}$ & Reciter & Limited universalization \\
\hline $\begin{array}{l}\text { عودسوز هاى مسىى } \\
\text { /Oud suz hāye mesil }\end{array}$ & Brass incense burner & Synonymy \\
\hline $\begin{array}{l}\text { جزوه جز } \\
\text { /Jozve chil }\end{array}$ & ---- & Deletion \\
\hline $\begin{array}{l}\text { تُنَ شاخدار } \\
\text { /Tong-e Shakhdār/ }\end{array}$ & Crystal decanter & Limited universalization \\
\hline $\begin{array}{l}\text { لفت و ليس جى } \\
\text { /Lefto lis chil }\end{array}$ & Parasite & Synonymy \\
\hline $\begin{array}{l}\text { نطata'/ } \\
\text { /nat }\end{array}$ & Decapitations & Deletion \\
\hline أl & Harem & Orthographic adaptation \\
\hline $\begin{array}{l}\text { جُركَه جُه } \\
\text { Jorge chil }\end{array}$ & Beaters & Synonymy \\
\hline $\begin{array}{l}\text { جليكه } \\
\text { /Chelikel }\end{array}$ & Jerkin & Autonomous creation \\
\hline IDade/ & Nanny & Synonymy \\
\hline $\begin{array}{l}\text { قليان } \\
\text { /Ghelyan/ }\end{array}$ & Water pipe & Linguistic translation \\
\hline $\begin{array}{l}\text { صيغه و عقدى } \\
\text { /Sighe-o-Aghdi/ }\end{array}$ & Wedded or temporary & Limited universalization \\
\hline $\begin{array}{l}\text { ميرغضب باشتى } \\
\text { /Mir ghazab bashi/ }\end{array}$ & Lord of wrath & Extratextual gloss \\
\hline 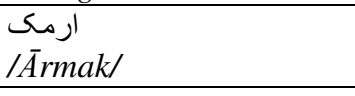 & Pinafore & Synonymy \\
\hline $\begin{array}{l}\text { جֶּ } \\
\text { /Chopogh/ }\end{array}$ & Pipe & Synonymy \\
\hline $\begin{array}{l}\text { دستى } \\
\text { /Dastak/ }\end{array}$ & Basin & Limited universalization \\
\hline $\begin{array}{l}\text { خفيه نويس } \\
\text { /Khafie nevis/ }\end{array}$ & Spy & Limited universalization \\
\hline 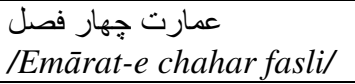 & A house for four seasons & Naturalization \\
\hline 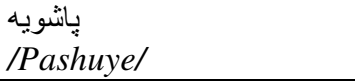 & The next step down & Linguistic translation \\
\hline $\begin{array}{l}\text { ايلخانيان/ } \\
\text { /Ilkhānian/ }\end{array}$ & Paramount chief of the Qashqai & Intratextual gloss \\
\hline
\end{tabular}

Frequency of the all strategies used in the translating the culture-specific items in Prince Ehtejab are shown in this chart. It is obvious that synonymy, as a subcategory of Domestication, was the most frequent strategy in translating culture-specific items by James Buchan with thirty-nine percent.

At this point, it is needed to delineate the Domestication or Foreignization as the main approach of the translator. Therefore, according to Aixela's division, the strategies were divided into two groups. As already stated, repetition, orthographic adaptation, intratextual/extra textual translation, and linguistic (non-cultural) translation are in the Foreignization side, and the other strategies are all in Domestication side. After Adding up the strategies of each side, it is concluded that 6 Foreignization strategies and 28 Domestication strategies are seen in translation of Shazdeh Ehtejab by James Buchan. 


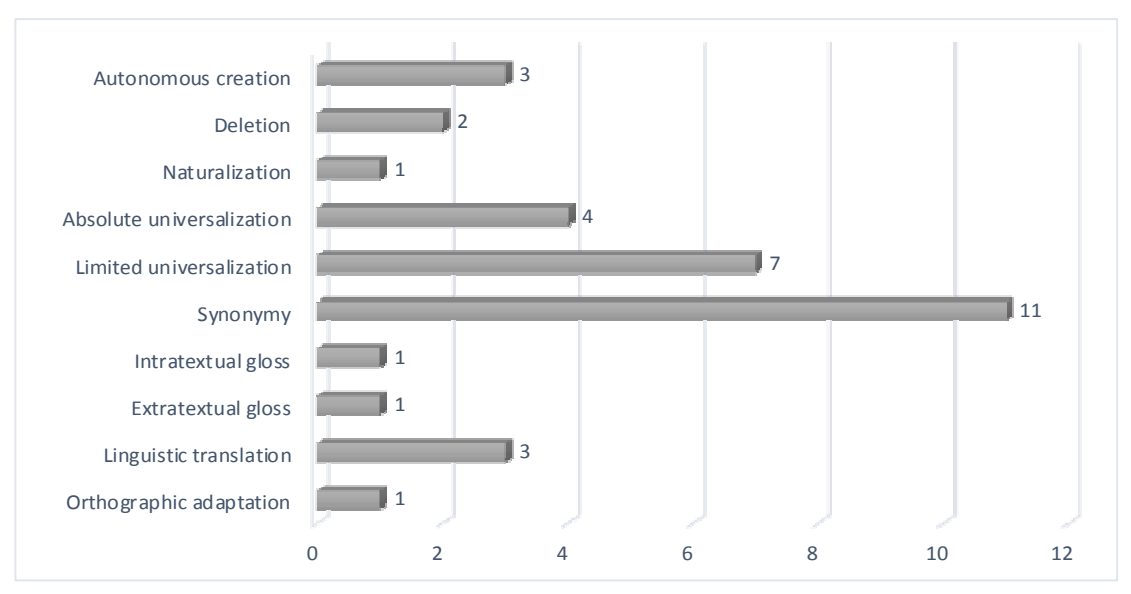

Figure 1. Frequency of strategies

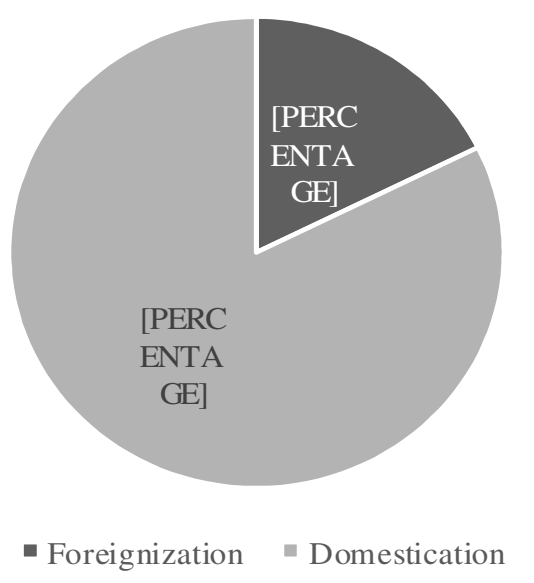

Figure 2. Domestication and Foreignization frequency

As shown in Figure 2, Domestication with 28 occurrences or $82 \%$ is more frequent, which stands as the main approach of James Buchan in translating Shazdeh Ehtejab's culture-specific items.

Few studies have been done Persian to English cultural translation. Hosseini (2007) studied the concepts of Domestication and Foreignization. The researcher compared three Persian novels with their translations to English, and three English novels with their translations to Persian. She found that Domestication and Foreignization are equally employed and Domestication is not specific to the Anglo-American translators.

In another study, Emrani (2008) investigated Foreignization and Domestication in the English translation of the Holy Qur'an. Emrani found that Foreignization is the most frequent strategy. Translating sacred text is another category that differs a lot with the process of literary translation. A reason of that could be the divine source, which acquires sameness in the target language. In the same way, Pakatchi (2008) attempted to investigate Domestication and Foreignization in translations of the children's literature and its relationship with the passing of time. The researcher found that children's literature is more domesticated, and time is a determining factor. Again, children's literature has its own features. Since children do not have enough understanding of another culture, mostly in third-world countries.

Validashti (2008) explored Domestication and Foreignization in five novels of the Harry Potter series and their translated versions. The researcher found that $77.5 \%$ of the procedures were Domestication and only $22.5 \%$ of the procedures were Foreignization. The results of Validashti's study are aligned with the results of this study, in that Domestication is used more frequently. In a similar study, Pralas (2012) investigated the Domestication 
Translating culture-specific items in Shazdeh Ehtejab: Examining Foreignization and Domestication

and Foreignization strategies of the French culture-specific in Julian Barnes's Flaubert Parrot. Pralas found that in many cases the translator could not do anything else, but make himself visible in translation by providing intra-textual or extra-textual glosses. Pralas' study showed that Foreignization is more frequent, which leads to visibility of the translator. The results of Pralas' study reiterate what was found in this study, which is Domestication leads to invisibility of the translator, mainly, in the English translation of Shazdeh Ehtejab.

Vahedi (2012) studied Domestication, Foreignization, and the translator's invisibility. Her research was mainly concerned with whether or not Domestication leads to the translator's invisibility. The corpus of the study was novels with Slavery and Depression as their topic and their translations into Persian. The results of this study showed that translators use Foreignization along with Domestication, and consequently, translators cannot be that invisible always assumed. The results of Vahedi's study are not aligned with the results of this study. A problem for that study could be the corpus she used was English to Persian translations. Since, translator's invisibility is applied on the Anglo-American culture, and consequently, Anglo-American translators.

The concepts of Foreignization and Domestication can also be applied to other languages. Venuti (1995) delineated on these two concepts when there is translational transfer from a cultural other to the Anglo-American culture. Therefore, all other languages, especially minor languages, can track this trend in the process of the translations made from their language and culture to the language of power, i.e. English language. The important point here is that the translator of the literary work should be a member of the Anglo-American culture. However, non-native translators may also bend to the canon of fluency which is dictated to translators in English language through the presence of publishers.

\section{Conclusion}

Culture emerges in language in form of literature. Translating literary works is of great significance, since it deals with transference of cultures between languages. The culturally loaded lexical items are called culture-specific items. The importance of the culture in translation studies was augmented by the cultural turn in 1990s.

In the present study, the author studied culture-specific items in the English translation of the Persian literary masterpiece, Shazdeh Ehtejab, to see the way its culture-specific items are behaved. The novel is immersed in the Persian culture; therefore, it arouses difficulty for the translator of the novel, James Buchan. To do so, thirty-four culture-specific items were categorized according to Newmark's categorization (1988) of culture-specific items. Then these items were analyzed according to Aixela's model (1966) of translating culture-specific items to find the way each item is translated into English. The results showed that synonymy, as a subcategory of Domestication, with 39 percent was the most frequent strategy in translating culture-specific items by James Buchan in the translation of Shazdeh Ehtejab. Aixela, then, divided the strategies into two groups: repetition, orthographic adaptation, intratextual and extratextual translation, and linguistic (non-cultural) translation are in the Foreignization side, and synonymy, limited universalization, absolute universalization, naturalization, deletion, and autonomous creation are all in the Domestication side. After adding up each side, it was concluded that Domestication with 28 occurrences, or 82 percent, was more frequent, which stood as the main approach of the translator.

This study hinges on the old discussion of the "the translatability of culture". Yet again, it is approved that culture is not easily transferred across languages. The reason of this may lay in the Edward Hall's so-called Iceberg model, the Triad of Culture, that is culture-specific items may be available only in the semi-visible or the invisible level, which are both below the waterline. The findings of this study have pedagogical implications for literary translators. Novice literary translators may use the findings as a guideline for their translation process, mostly from minor to major languages. 


\section{References}

Aixela, J. F. (1996). Culture-specific items in translation. In R. Alvarez \& M. Carmen-Africa Vidal (Eds.), Translation, power, subversion (pp. 52-78). Clevedon: Multilingual Maters.

Amid, H. (2013). Amid dictionary. Tehran: Amir Kabir.

Baker, M. (1992). In other words: A course book on translation. London and New York: Routledge. http://dx.doi.org/10.4324/9780203327579

Baker, M., \& Saldanha, G. (2009). The Routledge encyclopedia of translation studies ( $2^{\text {nd }}$ ed). London: Routledge.

Bassnett, S. (2002). Translation studies ( $3^{\text {rd }}$ ed.). USA and Canada: Routledge.

Buchan, J. (2005). The prince. London: Harvil Secker.

Catford, J. C. (1965). A linguistic theory of translation. London: Oxford University Press.

Dehkhoda, A. (1994). Dehkhoda dictionary. Tehran: Amir Kabir.

Emrani, A. (2008). Foreignization and Domestication in the English translation of the holy Qur'an. Unpublished masteral thesis, Allameh Tabataba'i University, Iran.

Florin, S. (1993). Realia in translation. In P. Zlateva (Ed.), Translation as social action: Russian and Bulgarian perspectives (pp. 122-128). London: Routledge.

Golshiri, H. (2005). Shazdeh Ehtejab (14 ${ }^{\text {th }}$ ed.). Tehran: Niloufar.

Hatim, B., \& Munday, J. (2004). Translation: An advanced resource book. USA and Canada: Routledge.

Hongwei, C. (1999). Cultural difference and translation. Translation Journal, 44, 121-132.

Katan, D. (2009). Culture. In M. Baker \& G. Saldanha (Eds.), The Routledge encyclopedia of translation studies (pp. 70-73). London: Routledge.

Lefevere, A. (1977). Translating literature: The German tradition from Luther to Rosenzweig. Assen: Van Gorcum.

Moin, M. (2005). Moin dictionary. Tehran: Amir Kabir.

Newmark, P. (1988). A textbook of translation. London: Prentice Hall.

Pakatchi, K. (2008). Foreignization and Domestication in the English translation of children literature. Unpublished Masteral thesis, Allameh Tabataba'i University, Iran.

Pralas, J. (2012). Translating French culture-specific items in Julian Barnes's Flaubert's Parrot. Linguistics and Literature, 10(1), 11-18.

Pym, A. (2010). Exploring translation studies. USA and Canada: Routledge.

Sturge, K. (2009). Cultural translation. In M. Baker \& G. Saldanha (Eds.), The Routledge encyclopedia of translation studies (pp. 67-70). London: Routledge.

Toury, G. (2000). The nature and role of norms in translation. In L. Venuti (Ed.), The translation studies reader (pp. 205-218). London and New York: Routledge.

Trivedi, H. (2005). Translating culture vs. cultural translation. The University of IOWA. Retrieved January 12 , 2013, from http://www.uiowa.edu/ iwp/91st/91st_Archive/vol4_n1/pdfs/trivedi.pdf

Vahedi, M. (2012). Domestication and Foreignization and translator's invisibility. Unpublished Masteral thesis, Allameh Tabataba'i University, Iran.

Validashti, F. (2008). Domestication, Foreignization and identity Issues: A comparative study of translated novels. Unpublished MA Thesis, Islamic Azad University, Science and Research Branch, Iran.

Venuti, L. (1995). The translator's invisibility: A history of translation. London: Routledge. http://dx.doi.org/10.4324/9780203360064

Williams, J., \& Chesterman, A. (2002). The map. Manchester: St. Jerome. 